\title{
THE DISCHARGE RELATED LEARNING NEEDS OF HEMATOPOIETIC STEM CELL TRANSPLANT RECIPIENTS
}

\author{
Hematopoetik Kök Hücre Alıcılarının Taburculuk Aşamasında Öğrenme Gereksinimleri \\ Emine DERYA ISTER ${ }^{1}$ (1) Emine KAPLAN SERIN ${ }^{2}$ (1) Berna BAYIR ${ }^{3}$ (1) $\quad$ Mehmet Ali ERKURT ${ }^{4}$ (])

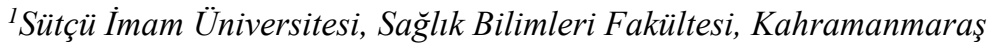 \\ ${ }^{2}$ Munzur Üniversitesi Sağllk Bilimleri Fakültesi, Tunceli \\ ${ }^{3}$ KTO Karatay Üniversitesi, Sağglk Bilimleri Yüksekokulu, Konya \\ ${ }^{4}$ İönü Üniversitesi, Turgut Özal Tip Merkezi, Malatya
}

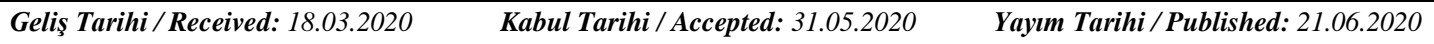

\begin{abstract}
This study has been carried out to determine the learning needs of patients undergoing hematopoietic stem cell transplantation at the discharge stage. 100 patients undergoing transplantation in the Stem Cell Transplantation Unit of a university hospital in Turkey in 2018 have constituted the sample of the study. The "Patient Information Form" and the "Patient Learning Needs Scale" have been used as data collection tools in the study. In the study, the data have been collected 2-48 hours before the patients were discharged. The mean total score of the Patient Learning Needs Scale of the patients is $212.93 \pm 29.37$, and the learning needs of the patients are generally high. The mean score of the treatment and complications subscale is $4.40 \pm 0.61$, and the level of significance of the patients' learning needs is highest in this dimension. This is followed by; quality of life, drugs, life activities, community and followup, skin care and feelings about the condition, respectively. The mean total score of the scale was not affected by gender, marital status, employment status, existing chronic disease, educational level, and type of transplantation $(\mathrm{p}>0.05)$. It was concluded that the learning needs of each patient undergoing hematopoietic stem cell transplantation were high.
\end{abstract}

Keywords: Discharge, Hematopoietic stem cell transplantation, Learning needs, Patient

\section{ÖZ}

$\mathrm{Bu}$ araştırma, hematopoetik kök hücre nakli uygulanan hastaların taburculuk aşamasında öğrenme gereksinimlerini belirlemek amacıyla yapılmıştır. Araştırmanın örneklemini Türkiye'de bir üniversite hastanesinin Kök Hücre Nakil Ünitesinde 2018 yılında nakil olan 100 hasta oluşturmuştur. Araştırmada veri toplama aracı olarak "Hasta Bilgi Formu" ve "Hasta Öğrenme Gereksinimleri Ölçeği" kullanılmıştır. Araştırmada veriler hasta taburcu olamadan 2-48 saat önce toplanmıştır. Hastaların ölçek toplam puan ortalaması $212.93 \pm 29.37$ olup, hastaların genel olarak öğrenme gereksinimleri yüksektir. Tedavi ve Komplikasyonlar alt boyut puan ortalaması $4.40 \pm 0.61$ olup hastaların öğrenme gereksinimlerinin en yüksek olduğu boyuttur. Bunu sırasıyla yaşam kalitesi, ilaçlar, yaşam aktiviteleri, toplum ve izlem, cilt bakımı ve duruma ilişkin duygular izlemektedir. Ölçek toplam puan ortalamasını cinsiyet, medeni durum, çalışma durumu, mevcut kronik hastalık, eğitim düzeyi, nakil tipi etkilememektedir ( $p>0.05)$. Hematopoetik kök hücre nakli uygulanan her hastanın öğrenim gereksinimlerinin yüksek olduğu sonucuna ulaşılmıştır.

Anahtar kelimeler: Hastalar, Hematopoetik kök hücre transplantasyonu, Öğrenme gereksinimi, Taburculuk 


\section{INTRODUCTION}

Cancer, which is a major health problem all over the world and in our country today (Kurt \& Unsar, 2011), negatively affects the physical and psychological health and the social and economic status of the patients and also caregiver family members due to its high cost and the problems related to the disease process and treatment (Görgülü \& Akdemir, 2010). Hematopoietic stem cell transplantation (HSCT), which is one of the cancer treatment methods, and high dose chemotherapy treatment in relation to it may lead to physical, psychosocial and mental problems in patients (Kapucu \& Karacan, 2008; Pehlivan, Vatansever, Arslan, Yildiz \& Ersoy, 2019; Şahin, Polat \& Ergüney, 2009). Before and after transplantation, patients face neutropenia, infection, bleeding, pain, fatigue, nausea and vomiting, dehydration, diarrhea, mucositis, changes in the skin and nails, and mental problems (Kurt \& Unsar, 2011; Ovayolu, Ovayolu, Kaplan, Pehlivan \& Karadağ, 2013) which also negatively affects the quality of life of caregivers (El-Jawahri et al., 2015). For these reasons, post-treatment care and follow up responsibilities of cancer patients and their families increase (Dursun Başaran \& Y1lmaz, 2015; Polat, 2011). The individuals who are discharged may have problems related to complications, drug treatment, performing activities of daily living, and symptoms, usually in the first weeks at home. While patients change their lifestyles, they also have problems with their family and friendship relations and difficulties in returning to their previous social activities. While family members who provide primary care to cancer patients undergoing transplantation fulfill all patient supporting roles, they often experience stress since their patients are not ready for care at home. Cancer patients are affected by this condition, which is reflected in their symptoms (Polat, 2011). So, when patients cannot solve the problems they face in treatment and home care, the need for repeated hospital attendments and even hospitalization increase (Soyer, Candan Dönmez \& van Giersbergen Yavuz, 2018). Patients should be aware of the symptoms so that they can cope with the symptoms they have experienced when they are discharged after transplantation (Kurt \& Unsar, 2011). Therefore, it is important to inform and support the cancer patient and his/her family (Yılmaz Şahin, İyigün \& Açıkel, 2015).

A good discharge education is required for the patients to be protected from complications, to detect possible complications in the early period, to perform their self-care, to support their own care and to maintain their home care and treatment (Dursun Başaran \& Y1lmaz, 2015; Soyer et al., 2018). Nurses, who are in personal contact with the patient/family during the treatment and 
care process, have a significant role in the planning and implementation of discharge education (Çetinkaya \& Duru Aşiret, 2017; Dursun Başaran \& Y1lmaz, 2015; Güçlü \& Kurşun, 2017; Tan, Özdelikara \& Polat, 2013). Nurses should prepare an education plan appropriate to the patient's needs and individual characteristics in order to achieve the aim of the patient education before performing it (Çetinkaya \& Duru Aşiret, 2017; Dursun Başaran \& Yılmaz, 2015; Kılıç, Bağçivan, Akbayrak \& Çiçek, 2018; Pehlivan et al., 2019). The determination of individual needs will make the education provided to the patient more beneficial and efficient (Çetinkaya \& Duru Aşiret, 2017; Dursun Başaran \& Y1lmaz, 2015; Orgun \& Şen, 2012).

Conscious nursing interventions are effective in preventing and reducing post-transplant complications of patients (Kurt \& Unsar, 2011; Pehlivan et al., 2019). Based on these data, this study was planned to determine the learning needs of cancer patients with hematopoietic stem cell transplantation and to develop appropriate nursing practices.

\section{MATERIALS AND METHODS}

\section{Type of Study}

This study was carried out as a descriptive cross-sectional study in order to determine the learning needs of the patients undergoing HSCT at the discharge stage, and the associated factors.

\section{Population and Sample}

The patients who were hospitalized in the Stem Cell Transplantation Unit of a medical school hospital in Malatya province between 01.01.2018 and 31.12.2018 and underwent HSCT constituted the population of the study. The inclusion criteria for the study were being 18 years and older, speaking Turkish, and lack of mental disorder. The sample of the study consisted of 100 patients who met the inclusion criteria and agreed to participate in the study.

\section{Data Collection Tools}

The "Patient Information Form", and the "Patient Learning Needs Scale (PLNS)" aimed at determining patients' needs for discharge education were used as data collection tools in the study. In the study, the data were collected 2-48 hours before the patients were discharged.

\section{Patient Learning Needs Scale (PLNS)}

The "Patient Learning Needs Scale (PLNS)", which was first developed by Bubela and et al., in 1990 and adapted to Turkish by Çatal and Dicle in 2008 was used to determine the 
information needs of patients at the discharge stage (Bubela et al., 1990; Çatal \& Dicle, 2008). The scale consists of a total of 50 items and 7 subscales (Table 1). Information on the number of items of the total scale and its subscales, item numbers and minimum, and the lowest and highest values that can be obtained from the scale and its subscales are presented in Table 1 . The scale items are rated as " $1=$ unimportant", " $2=$ slightly important", " $3=$ moderately important", " $4=$ very important", "5= extremely important" by likert-type scaling method. Accordingly, patients are asked to choose the option that best describes their information needs and priorities before being sent home prior to discharge. The scale is rated based on total scores of each sub-dimension and the scale. The highest and lowest scores to be obtained from the scale are 250 and 50, respectively. Scale and subscale scores are calculated by dividing the total scale and the number of questions of all subscales according to the level of significance between 1 and 5 as " $1=$ unimportant", " $2=$ slightly important", " $3=$ moderately important", " $4=$ very important", " $5=$ extremely important” (Bubela et al., 1990; Çatal \& Dicle, 2008). In this study, Cronbach's alpha value of the scale was found to be 0.96 .

Table 1. Number of items and item scores of the PLNS and its subscales

\begin{tabular}{|c|c|c|c|c|}
\hline Scale & $\begin{array}{l}\text { Number of } \\
\text { Items }\end{array}$ & Item Numbers & Min- Max & 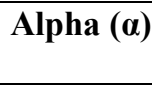 \\
\hline Medications & 8 & $3,8,16,18,37,39,44,45$ & $8-40$ & 0.85 \\
\hline Activities of Living & 9 & $2,5,14,17,27,28,29,30,48$ & $9-45$ & 0.83 \\
\hline Community and Follow-up & 6 & $6,9,22,31,36,41$ & $6-30$ & 0.77 \\
\hline $\begin{array}{l}\text { Feelings related to } \\
\text { Condition }\end{array}$ & 5 & $7,24,32,35,42$ & $5-25$ & 0.77 \\
\hline $\begin{array}{l}\text { Treatment and } \\
\text { Complications }\end{array}$ & 9 & $1,4,10,19,20,23,26,38,47$ & $9-45$ & 0.86 \\
\hline Quality of Life & 8 & $11,13,15,21,34,40,46,50$ & $8-40$ & 0.84 \\
\hline Skincare & 5 & $12,25,33,43,49$ & $5-25$ & 0.73 \\
\hline Total & 50 & & $50-250$ & 0.96 \\
\hline
\end{tabular}

\section{Ethical approval}

Munzur University ethical committee approval was obtained to carry out the study (1-42018). Written permissions were obtained from Malatya Inonu University Turgut Özal Medical Center and the patients.

\section{Statistical analyses}

The data were evaluated in the SPSS 17 package program. Descriptive statistics and Student-t test, one-way analysis of variance, Kruskal Wallis test, Mann Whitney U test were 
used. Total Cronbach's alpha values of the PLNS and its sub-dimensions were calculated for the sample group.

\section{RESULTS}

While $31 \%$ of the patients in the study were in the $18-40$ age range, $36 \%$ of them were in the $41-56$ age range and $33 \%$ of them were in the $57-76$ age range. While $63.0 \%$ of the patients were male, $72 \%$ of them were married and $45 \%$ of them were primary school graduates. It was determined that $84.0 \%$ of the patients were unemployed. When the medical diagnoses of the patients were examined, it was found that $28 \%$ of them had acute myeloid leukemia, $25 \%$ of them had multiple myeloma, and 15\%of them had acute lymphocytic leukemia. $61.0 \%$ of patients did not have any additional chronic disease. $53.0 \%$ and $47.0 \%$ of the patients underwent autologous stem cell transplantation and allogeneic stem cell transplantation, respectively. The lengths of stay of $38 \%$ and $33.0 \%$ of the patients were $21-40$ days and 14-20 days, respectively (Table 2).

Table 2. Some characteristics of patients

\begin{tabular}{lcc}
\hline & Number (n) & Percentage (\%) \\
\hline Age & 31 & 31.0 \\
18-40 years & 36 & 36.0 \\
41-56 years & 33 & 33.0 \\
57-76 years & & \\
\hline Gender & 37 & 37.0 \\
Female & 63 & 63.0 \\
Male & & \\
\hline Marital status & 28 & 28.0 \\
Single & 72 & 72.0 \\
Married & & \\
Educational level & 45 & 45.0 \\
Primary school & 26 & 26.0 \\
Secondary school & 16 & 16.0 \\
High school & 13 & 13.0 \\
University & & \\
\hline Employment Status & 16 & 16.0 \\
Employed & 84 & 84.0 \\
Unemployed & &
\end{tabular}




\begin{tabular}{lcc}
\hline Medical Diagnosis & & \\
Acute lymphocytic leukemia & 15 & 15.0 \\
Acute myeloid leukemia & 28 & 28.0 \\
Non-Hodgkin lymphoma & 11 & 11.0 \\
Multiple myeloma & 25 & 25.0 \\
Chronic myeloid leukemia & 2 & 2.0 \\
Hodgkin Disease & 2 & 2.0 \\
Aplastic Anemia & 6 & 6.0 \\
Thalassemia & 2 & 2.0 \\
Other & 9 & 9.0 \\
\hline Chronic Disease History & 39 & \\
Yes & 61 & 39.0 \\
No & & 61.0 \\
\hline Type of Transplantation & 53 & 53.0 \\
Autologous & 47 & 47.0 \\
Allogeneic & & \\
Length of stay & 33 & 33.0 \\
14-20 days & 38 & 38.0 \\
21-40 days & 29 & 29.0 \\
\hline days and more (max.250 days) & & \\
\hline
\end{tabular}

In our study, the mean total score of the PLNS of the patients undergoing HSCT was found to be $213.07 \pm 29.28$. The mean scores obtained from the subscales of the scale were medications $35.03 \pm 5.01$, activities of living $37.98 \pm 5.70$, community and follow-up $24.98 \pm 4.21$, feelings related to condition $19.94 \pm 3.90$, treatment and complications $39.62 \pm 5.49$, quality of life $35.13 \pm 4.69$ and skincare $20.39 \pm 3.77$, respectively. When the levels of significance of the patients from the sub-scales of the PLNS were examined, it was determined that they had the highest level of significance score in the subscales of treatment and complications (4.6) and medications (4.5) (Table 3).

Table 3. Mean scores of the patients from the patient learning needs scale and its subscales $(n=100)$

\begin{tabular}{lccc}
\hline \multicolumn{1}{c}{ Scale and its Subscales } & Min.-Max. & mean \pm Sd & $\begin{array}{c}\text { Level of Significance } \\
\text { (median) }\end{array}$ \\
\hline Medications & & & 4.5 \\
\hline Activities of Living & $15-40$ & $35.03 \pm 5.01$ & 4.2 \\
\hline Community and Follow-up & $24-45$ & $37.98 \pm 5.70$ & 4.1 \\
\hline Feelings related to Condition & $12-30$ & $24.98 \pm 4.21$ & 4.1 \\
\hline Treatment and Complications & $8-25$ & $19.94 \pm 3.90$ & 4.6 \\
\hline Quality of Life & $23-45$ & $39.62 \pm 5.49$ & 4.5 \\
\hline Skincare & $19-40$ & $35.13 \pm 4.69$ & 4.2 \\
\hline Total & $5-25$ & $20.39 \pm 3.77$ & 4.3 \\
\hline
\end{tabular}

While no difference was found between the total PLNS and the mean scores of the subscales of activities of living, community and follow-up, feelings related to condition, quality of life and skincare according to age groups, a statistically significant difference were found 
between the mean scores of the subscales of medications and treatment and complications $(\mathrm{p}<0.05)$. The mean score of patients between the ages of 18-40 was higher compared to other age groups.

Total PLNS and subscale mean scores did not vary by gender ( $p>0.05)$. A statistically significant difference was found between the total PLNS and the mean scores of the subscales of medications, activities of living, treatment and complications, and Skincare according to marital status $(\mathrm{p}<0.05)$. The total PLNS and the mean scores of medications, activities of living, treatment and complications, skincare were statistically significantly higher compared to married patients.

No statistically significant difference was found between the total PLNS and the mean scores of the subscales according to the educational level of the patients $(\mathrm{p}>0.05)$. Total PLNS and its subscales did not vary according to the presence of chronic disease accompanying the existing disease $(\mathrm{p}>0.05)$. Total PLNS and subscale mean scores did not vary according to the employment status, type of transplantation and length of stay of the patients $(p>0.05)$ (Table 4). 
Table 4. Total PLNS and subscale mean scores according to some characteristics of patients

\begin{tabular}{|c|c|c|c|c|c|c|c|c|}
\hline Variable & Medications & $\begin{array}{l}\text { Activities of } \\
\text { Living }\end{array}$ & $\begin{array}{l}\text { Community } \\
\text { and Follow-up }\end{array}$ & $\begin{array}{l}\text { Feelings } \\
\text { related to } \\
\text { Condition }\end{array}$ & $\begin{array}{l}\text { Treatment and } \\
\text { Complications }\end{array}$ & $\begin{array}{l}\text { Quality of } \\
\text { Life }\end{array}$ & Skincare & Total \\
\hline \multicolumn{9}{|l|}{ Age } \\
\hline $18-40$ years & $36.90 \pm 4.74$ & $39.93 \pm 5.85$ & $25.51 \pm 4.76$ & $20.16 \pm 4.76$ & $41.83 \pm 4.66$ & $36.41 \pm 4.58$ & $20.93 \pm 4.50$ & $221.70 \pm 30.48$ \\
\hline 41-56 years & $34.08 \pm 5.12$ & $37.30 \pm 5.88$ & $25.11 \pm 3.55$ & $20.25 \pm 3.27$ & $38.75 \pm 5.51$ & $35.05 \pm 4.45$ & $20.52 \pm 3.72$ & $211.80 \pm 27.67$ \\
\hline \multirow{3}{*}{$57-76$ years } & $33.51 \pm 5.01$ & $36.87 \pm 5.00$ & $24.33 \pm 4.37$ & $19.39 \pm 3.90$ & $38.48 \pm 5.72$ & $34.00 \pm 4.88$ & $19.72 \pm 3.01$ & $206.33 \pm 28.67$ \\
\hline & $\mathrm{F}=3.93$ & $\mathrm{~F}=2.78$ & $\mathrm{~F}=0.65$ & $\mathrm{~F}=0.48$ & $\mathrm{~F}=3.90$ & $\mathrm{~F}=2.17$ & $\mathrm{~F}=0.85$ & $\mathrm{~F}=2.31$ \\
\hline & $\mathrm{p}=\mathbf{0 . 0 2 3}$ & $\mathrm{p}=0.066$ & $\mathrm{p}=0.523$ & $\mathrm{p}=0.620$ & $p=0.023$ & $\mathrm{p}=0.119$ & $\mathrm{p}=0.428$ & $\mathrm{p}=0.104$ \\
\hline \multicolumn{9}{|l|}{ Gender } \\
\hline Female & $35.08 \pm 4.90$ & $38.24 \pm 5.05$ & $24.97 \pm 3.86$ & $19.62 \pm 4.03$ & $39.56 \pm 5.25$ & $34.62 \pm 4.48$ & $20.27 \pm 4.23$ & $212.37 \pm 28.82$ \\
\hline \multirow[t]{3}{*}{ Male } & $35.00 \pm 5.11$ & $37.82 \pm 6.08$ & $24.98 \pm 4.43$ & $20.12 \pm 3.84$ & $39.65 \pm 5.66$ & $35.42 \pm 4.82$ & $20.46 \pm 3.50$ & $213.47 \pm 29.76$ \\
\hline & $\mathrm{t}=0.07$ & $\mathrm{t}=0.35$ & $t=-0.01$ & $t=-0.62$ & $t=-0.07$ & $\mathrm{t}=-0.82$ & $t=-0.24$ & $\mathrm{t}=-0.18$ \\
\hline & $\mathrm{p}=0.938$ & $\mathrm{p}=0.725$ & $\mathrm{p}=0.990$ & $\mathrm{p}=0.535$ & $\mathrm{p}=0.942$ & $\mathrm{p}=0.410$ & $\mathrm{p}=0.809$ & $\mathrm{p}=0.857$ \\
\hline \multicolumn{9}{|l|}{ Marital status } \\
\hline Single & $36.42 \pm 5.58$ & $39.57 \pm 5.89$ & $25.71 \pm 4.36$ & $20.57 \pm 3.91$ & $41.78 \pm 3.73$ & $36.50 \pm 3.74$ & $21.57 \pm 3.57$ & $222.14 \pm 26.63$ \\
\hline \multirow[t]{3}{*}{ Married } & $34.48 \pm 4.59$ & $37.36 \pm 5.54$ & $24.69 \pm 4.15$ & $19.69 \pm 3.90$ & $38.77 \pm 5.84$ & $34.59 \pm 4.93$ & $19.93 \pm 3.76$ & $209.54 \pm 29.67$ \\
\hline & $\mathrm{U}=669.0$ & $\mathrm{U}=741.0$ & $\mathrm{U}=828.5$ & $\mathrm{U}=857.0$ & $\mathrm{U}=687.0$ & $\mathrm{U}=783.5$ & $\mathrm{U}=\mathbf{7 3 0 . 0}$ & $\mathrm{U}=724.0$ \\
\hline & $p=0.009$ & $\mathrm{p}=\mathbf{0 . 0 4 0}$ & $\mathrm{p}=0.166$ & $\mathrm{p}=0.244$ & $\mathrm{p}=\mathbf{0 . 0 1 3}$ & $\mathrm{p}=0.082$ & $\mathrm{p}=\mathbf{0 . 0 3 2}$ & $\mathrm{p}=\mathbf{0 . 0 2 9}$ \\
\hline \multicolumn{9}{|l|}{ Educational level } \\
\hline Primary school & $33.84 \pm 5.58$ & $37.40 \pm 5.70$ & $25.02 \pm 4.12$ & $19.88 \pm 3.56$ & $38.55 \pm 5.88$ & $34.40 \pm 4.78$ & $20.51 \pm 3.55$ & $209.62 \pm 30.77$ \\
\hline Secondary school & $35.03 \pm 4.56$ & $37.34 \pm 5.86$ & $23.88 \pm 4.65$ & $19.30 \pm 4.46$ & $38.84 \pm 5.95$ & $34.76 \pm 5.36$ & $20.00 \pm 4.02$ & $209.19 \pm 30.56$ \\
\hline High school & $36.06 \pm 4.68$ & $39.06 \pm 6.25$ & $26.38 \pm 2.69$ & $20.25 \pm 4.65$ & $41.25 \pm 4.12$ & $36.00 \pm 4.30$ & $20.75 \pm 4.43$ & $218.87 \pm 29.57$ \\
\hline \multirow[t]{3}{*}{ University } & $37.84 \pm 2.54$ & $39.92 \pm 4.51$ & $24.98 \pm 4.21$ & $21.00 \pm 2.94$ & $42.84 \pm 2.47$ & $37.30 \pm 2.52$ & $20.30 \pm 3.44$ & $225.61 \pm 16.42$ \\
\hline & $\mathrm{KW}=7.65$ & $\mathrm{KW}=2.58$ & $\mathrm{KW}=2.84$ & $\mathrm{KW}=1.42$ & $\mathrm{KW}=7.33$ & $\mathrm{KW}=3.86$ & $\mathrm{KW}=0.83$ & $\mathrm{KW}=4.03$ \\
\hline & $\mathrm{p}=0.054$ & $\mathrm{p}=0.460$ & $\mathrm{p}=0.417$ & $\mathrm{p}=0.700$ & $\mathrm{p}=0.062$ & $\mathrm{p}=0.277$ & $\mathrm{p}=0.841$ & $\mathrm{p}=0.258$ \\
\hline \multicolumn{9}{|c|}{ Chronic Disease History } \\
\hline Yes & $33.87 \pm 5.23$ & $37.02 \pm 5.57$ & $24.25 \pm 4.19$ & $19.61 \pm 3.61$ & $38.56 \pm 5.49$ & $34.56 \pm 4.61$ & $20.12 \pm 3.38$ & $208.02 \pm 28.58$ \\
\hline \multirow[t]{3}{*}{ No } & $35.77 \pm 4.75$ & $38.59 \pm 5.74$ & $25.44 \pm 4.19$ & $20.14 \pm 4.10$ & $40.29 \pm 5.42$ & $35.49 \pm 4.74$ & $20.55 \pm 4.01$ & $216.29 \pm 29.49$ \\
\hline & $t=-1.87$ & $\mathrm{t}=-1.34$ & $\mathrm{t}=-1.37$ & $t=-0.66$ & $\mathrm{t}=-1.54$ & $t=-0.96$ & $\mathrm{t}=-0.55$ & $\mathrm{t}=-1.38$ \\
\hline & $\mathrm{p}=0.064$ & $\mathrm{p}=0.182$ & $\mathrm{p}=0.171$ & $\mathrm{p}=0.509$ & $\mathrm{p}=0.125$ & $\mathrm{p}=0.338$ & $\mathrm{p}=0.581$ & $\mathrm{p}=0.170$ \\
\hline \multicolumn{9}{|c|}{ Employment Status } \\
\hline Employed & $37.18 \pm 2.37$ & $39.87 \pm 5.16$ & $25.50 \pm 3.86$ & $20.81 \pm 2.99$ & $42.06 \pm 3.08$ & $37.12 \pm 3.30$ & $21.00 \pm 3.50$ & $223.56 \pm 19.74$ \\
\hline \multirow[t]{3}{*}{ Unemployed } & $34.61 \pm 5.27$ & $37.61 \pm 5.75$ & $24.88 \pm 4.29$ & $19.77 \pm 4.05$ & $39.15 \pm 5.73$ & $34.75 \pm 4.83$ & $20.27 \pm 3.82$ & $211.07 \pm 30.44$ \\
\hline & $\mathrm{U}: 511.50$ & $\mathrm{U}: 534.00$ & $\mathrm{U}: 636.00$ & $\mathrm{U}: 592.00$ & $\mathrm{U}: 507.00$ & $\mathrm{U}: 484.50$ & $\mathrm{U}: 588.00$ & $\mathrm{U}: 531.50$ \\
\hline & $\mathrm{p}=0.127$ & $\mathrm{p}=0.192$ & $\mathrm{p}=0.733$ & $\mathrm{p}=0.450$ & $\mathrm{p}=0.119$ & $\mathrm{p}=0.076$ & $\mathrm{p}=0.427$ & $\mathrm{p}=0.186$ \\
\hline
\end{tabular}




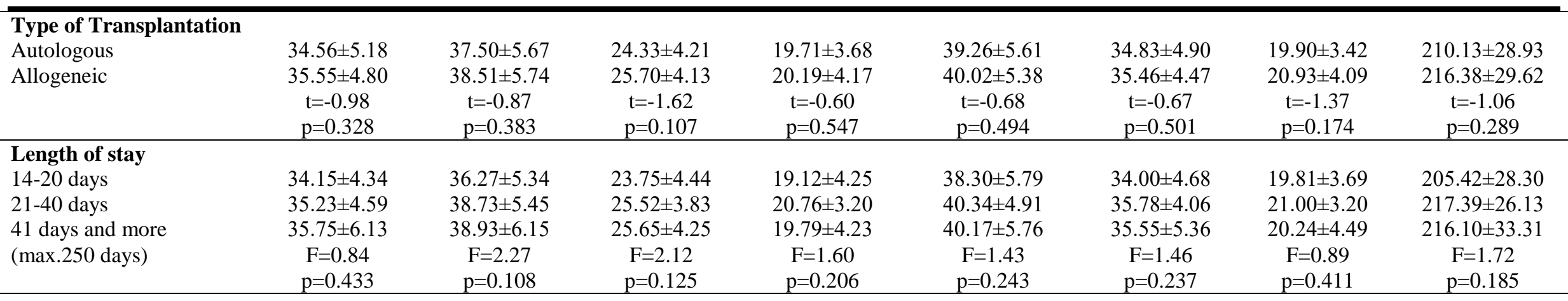




\section{DISCUSSION}

This study was carried out to determine the learning needs of patients undergoing hematopoietic stem cell transplantation at the discharge stage. It is recommended to increase the number of studies aimed at determining patient needs in the literature (Akkuzu et al., 2018). In our study, the mean total score of the PLNS of the patients undergoing HSCT was found to be $213.07 \pm 29.28$. When the levels of significance of the patients from the sub-scales of the PLNS were examined, it was determined that they had the highest level of significance score in the subscales of treatment and complications (4.6) and medications (4.5) (Table 3). In the studies carried out using the PLNS in different patient groups, the mean total score of the scale was found to be between 165.95 \pm 45.44 and 207.52 \pm 24.14 (Çetinkaya \& Duru Aşiret, 2017; Demirkıran \& Uzun, 2012; Dursun Başaran \&Yılmaz, 2015; Güçlü \& Kurşun, 2017; Özel \& Karabacak, 2012; Tan et al., 2013; Uzun, Ucuzal \& İnan 2011). In our study, the total score of the patients from the scale was found to be higher than the mean score to be obtained from the scale (150), as in the other which reveals that patients need information about their care at home studies (Demirkıran \& Uzun, 2012; Dursun Başaran \& Yılmaz, 2015; Güçlü \& Kurşun, 2017; Orgun \& Şen, 2012; Polat, 2011; Polat, Celik, Erkan \& Kasali, 2014; Tan et al., 2013; Uzun et al., 2011). Similarly, in other studies, the highest subscale score was determined as treatment and complications (Çetinkaya \& Duru Aşiret, 2017; Dursun Başaran \&Y1lmaz, 2015; Fagermoen \& Hamilton, 2006; Güçlü \& Kurşun, 2017; Jacobs, 2000; Orgun \& Şen, 2012; Polat, 2011; Şendir, Büyüky1lmaz \& Muşovi, 2013; Tan et al., 2013) and medications (Çetinkaya \& Duru Aşiret, 2017; Dağ, Dönmez, Güleç, Öztürk, Eminov \& Saruhan, 2014; Dursun Başaran \& Yılmaz, 2015; Güçlü \& Kurşun, 2017; Orgun \& Şen, 2012; Y1lmaz \& Özkan, 2015). The results of the study were similar to the literature, and the patients were mostly in need of information on medical issues related to discharge (complications and medication), which suggests that they wanted to increase their knowledge on this subject since they would take the responsibility for their own treatment in the home environment after discharge. Accurate information obtained on treatment and care will reduce the complications that may occur due to treatment, and will accelerate recovery and improve the quality of life (Çetinkaya \& Duru Aşiret, 2017).

While no difference was found between the total PLNS and the mean scores of the subscales of activities of living, community and follow-up, feelings related to condition, quality of life and skincare according to age groups, a statistically significant difference were found between the mean scores of the subscales of medications and treatment and 
complications. The mean score of patients between the ages of 18-40 was higher compared to other age groups. In the study carried out by Y1lmaz and Özkan 2015, no significant relationship was found between total PLNS score and age (Y1lmaz \& Özkan, 2015). On the other hand, in the study of Güçlü and Kurşun it was determined that the educational needs of the patients between the ages of 18-39 were high and that there was a statistically significant difference (Güçlü \& Kurşun, 2017). In the study of Tan et al., it was determined that the younger age groups had higher educational needs compared to other age groups (Tan et al., 2013). The fact that individuals in the 18-40 age range were less likely to experience disease compared to older age groups, were an active group in society by age and had increased responsibilities suggested that they would have higher needs for learning about discharge (Çetinkaya \& Duru Aşiret, 2017; Güçlü \& Kurşun, 2017).

Total PLNS and subscale mean scores did not vary by gender. The study of Güçlü and Kurşun supported our results. A statistically significant difference was found between the total PLNS and the mean scores of the subscales of medications, activities of living, treatment and complications, and skincare according to marital status. The total PLNS and the mean scores of medications, activities of living, treatment and complications, skincare were statistically significantly higher compared to married patients (Güçlü \& Kurşun, 2017). In the study carried out by Tan et al., the mean scores of the subscales of medications, community and follow-up and quality of life of single patients were found to be higher compared to married patients (Tan et al., 2013). In the study of Güçlü and Kurşun it was determined that marital status had an effect on learning needs. In the study of Taşdemir et al., it was determined that marital status had no effect on learning needs (Taşdemir, Güloğlu, Turan, Çatatepe \& Özbayır, 2010).

No statistically significant difference was found between the total PLNS and the mean scores of the subscales according to the educational level of the patients, which is similar to the results of Y1lmaz and Özkan (Y1lmaz \& Özkan, 2015). However, it was observed that educational needs increased as the educational level increased. In the study of Tan et al. (2013), it was reported that the learning needs of patients increased as the educational level increased (Tan et al., 2013). The results of our study are similar to the results of two studies (Tan et al., 2013; Yılmaz \& Özkan, 2015). Unlike our results, in the study carried out by Güçlü and Kurşun the need for discharge education of university graduates was found to be higher and there was a statistical difference (Güçlü \& Kurşun, 2017). Furthermore, in the study of Çetinkaya and Duru Aşiret, a statistically significant difference was found between 
the educational status of the patients and the subscales of the PLNS of feelings related to condition and skincare, however, there was no difference between the PLNS score (Çetinkaya \& Duru Aşiret, 2017). It is considered that this result was due to the fact that the patients with high educational levels had higher awareness and expectations compared to individuals with low educational level.

Total PLNS and its subscales did not vary according to the presence of chronic disease accompanying the existing disease. Total PLNS and subscale mean scores did not vary according to the employment status, type of transplantation and length of stay of the patients (Table 4). In the study of Güçlü and Kurşun no difference was found between the presence of chronic disease, urgency of surgical intervention, length of stay in the hospital, and discharge education, that were the health characteristics of patients, and total PLNS score (Güçlü \& Kurşun, 2017). In the study of Çetinkaya and Duru Aşiret., it was determined that the learning needs of the individuals with chronic disease were not significant compared to the individuals without chronic disease, however, the mean total score of the PLNS was higher (Çetinkaya \& Duru Aşiret, 2017). Unlike our results, in the study of Orgun and Şen, it was found that the need for learning increased as the length of stay of the patients staying in the surgical clinic increased (Orgun \& Şen, 2012).

\section{CONCLUSION}

As the result of the study, it was concluded that the information needs of the patients were high and that they had the highest information needs in the subscales of medications and treatment and complications. In our study, it was observed that there was no statistically significant difference between the demographic characteristics of individuals except marital status and the mean total score of the PLNS. In line with these results; it is recommended that a professional discharge education program should be prepared while informing the patient, what patients want to be informed about in the nursing process should be analyzed while planning the patient education, the socio-demographic variables should be considered while evaluating the learning needs of patients, evaluating the learning needs of family members because family members care for cancer patients. The study should be carried out with a larger sample group.

\section{REFERENCES}

Akkuzu, G., Kurt, G., Guvenc, G., Kok, G., Simsek, S., Dogrusoy, S., Ayhan, A. (2016). Learning needs of gynecologic cancer survivors. Journal of Cancer Education, 33(3), 544-550. 
Başaran Dursun, H., Yılmaz, E. (2015). Batın cerrahisi yapılan hastaların öğrenim gereksinimleri. Celal Bayar Üniversitesi Săglık Bilimleri Enstitüsü Dergisi, 2(3), 65-70.

Bubela, N., Galloway, S., Mccay, E., Mckibbon, A., Nagle, L., Pringle, D., ... Shamian, J. (1990). The patient learning needs scale: Reliability and validity. Journal of Advanced Nursing, 15(10), 1181-1187.

Çatal, E., Dicle, A. A. (2008). Validity and reliability study of the patient learning needs scale in Turkey. Dokuz Eylül Üniversitesi Hemşirelik Fakültesi Elektronik Dergisi, 1(1), 19-32.

Çetinkaya, F., Duru Aşiret, G. (2017). Dahili ve cerrahi kliniklerindeki hastaların öğrenim gereksinimlerinin belirlenmesi. Dokuz Eylül Üniversitesi Hemşirelik Fakültesi Elektronik Dergisi, 10(2), 93-99.

Dağ, H., Dönmez, S., Güleç, D., Öztürk, R., Eminov, A., Saruhan, A., Terek, M. Ç. (2014). Jinekolojik operasyon geçiren kadınların taburculuk öncesi öğrenim gereksinimleri. Ege Üniversitesi Hemşirelik Fakültesi Dergisi, 30(1), 49-59.

Demirkıran, G., Uzun, Ö. (2012). Koroner arter bypass greft ameliyatı geçiren hastaların taburculuk sonrası ögrenim gereksinimleri. Ege Üniversitesi Hemşirelik Fakültesi Dergisi, 28(1), 1-12.

El-Jawahri, A. R., Traeger, L. N., Kuzmuk, K., Eusebio, J. R., Vandusen, H. B., Shin, J. A., ... Temel, J. S. (2014). Quality of life and mood of patients and family caregivers during hospitalization for hematopoietic stem cell transplantation. Cancer, 121(6), 951-959.

Fagermoen, M.S., Hamilton, G. (2006). Patient information at discharge-A study of a combined approach. Patient Education and Counseling, 63(1-2), 169-176.

Görgülü, Ü., Akdemir, N. (2010). Ileri evre kanser hastalarına bakım verenlerin yorgunluk ve uyku kalitesinin değerlendirilmesi. Genel Tip Dergisi, 20(4), 125-132.

Güçlü, A., Kurşun, Ş. (2017). Genel cerrahi hastalarının taburculuk eğitim gereksinimleri. Anadolu Hemşirelik ve Sağlık Bilimleri Dergisi, 20(2), 107-113.

Jacobs, V. (2000). Informational needs of surgical patients following discharge. Applied Nursing Research, 13(1), $12-18$.

Kapucu, S.S., Karaca, Y. (2008). Kök hücre naklinde hasta değerlendirmesi. C.Ü. Hemşirelik Dergisi, 12, 52-59.

Kılıç, B., Băgçivan, G., Akbayrak, N., Çiçek, H. (2018). Kalp yetmezliği hastalarının öğrenme gereksinimleri envanteri'nin Türkçe geçerlik ve güvenirlik çalışmast. Anadolu Hemşirelik ve Sağllk Bilimleri Dergisi, 21(2), 79-88.

Kurt, S., Unsar, S. (2011). Assessment of symptom control in patients with cancer in Northwestern Turkey. European Journal of Oncology Nursing, 15(2), 137-144.

Orgun, F., Şen, G. (2012). Bir devlet hastanesinin cerrahi birimlerinde yatan hastaların ögrenim gereksinimlerinin saptanması. Uluslararası Hakemli Akademik Spor Sağlık ve Tıp Bilimleri Dergisi, 2(4), 52-64.

Ovayolu, Ö., Ovayolu, N., Kaplan, E., Pehlivan, M., Karadağ, G. (2013). Symptoms and quality of life before and after stem cell transplantation in Cancer. Pakistan Journal of Medical Sciences, 29(3), 803-808.

Özel, S., Karabacak, Ü. (2012). Discharge after surgical treatment: what do patients in turkey want to know? Health MED, 6(2), 525-530.

Pehlivan, S., Vatansever, N., Arslan, I., Yildiz, A., Ersoy, A. (2019). Level of daily life activities and learning needs in renal transplant patients. Exp Clin Transplant, 1(1), 1-7.

Polat, S., Celik,. S, Erkan, H. A., Kasali, K. (2014). Identification of learning needs of patients hospitalized at a university hospital. Pakistan Journal of Medical Sciences, 30(6), 1253-1258. 
Polat, Ü. (2011). Ileri evre kanser hastalarında semptom yönetiminde bakım verenin rolleri ve destek gereksinimleri. Türk Onkoloji Dergisi, 26(4), 193-198.

Soyer, Ö., Dönmez, Y. C., van Glersbergen Yavuz, M. (2018). Ameliyat olan hastaların ögrenim gereksinimlerinin belirlenmesi. Dokuz Eylül Üniversitesi Hemşirelik Fakültesi Elektronik Dergisi, 11(3), 200-208.

Şahin, Z. A., Polat, H., Ergüney, S.(2009). Kemoterapi alan hastalara bakım verenlerin bakım verme yüklerinin belirlenmesi. Atatürk Üniversitesi Hemșirelik Yüksekokulu Dergisi, 12(2), 1-9.

Şendir, M., Büyükyllmaz, F., Muşovi, D. (2013). Patients' discharge information needs after total hip and knee arthroplasty: A quasi-qualitative pilot study. Rehabilitation Nursing, 38(5), 264-271.

Tan, M., Özdelikara, A., Polat, H. (2013). Hasta öğrenim gereksinimlerin belirlenmesi. Florence Nightingale Hemşirelik Dergisi, 1(21), 1-8.

Taşdemir, N., Güloğlu, S., Turan, Y., Çataltepe, T., Özbayır, T. (2010). Learning needs of neurosurgery patients. Journal of Neurological Sciences, 27(4), 414-420.

Uzun, Ö., Ucuzal., M., Inan, G. (2011). Post-discharge learning needs of general surgery patients. Pakistan Journal of Medical Sciences, 27(3), 634-637.

Yılmaz Şahin, S., Iyigün., Açıkel C. (2015). Kolorektal kanser cerrahisi uygulanan hastaların bilgi gereksinimlerinin belirlenmesi. TAF Preventive Medicine Bulletin, 14(5), 401-405.

Yllmaz, E., Özkan, S. (2015). Learning needs of surgical patients. Anadolu Hemşirelik ve Sağlık Bilimleri Dergisi, 18(2), 107- 115. 